\title{
Hvordan forskes der i islam på Roskilde Universitet?
}

På Roskilde Universitet (RUC) er der ingen forskningsgrupper eller -enheder, der er defineret ved at beskæftige sig med islam eller muslimer. Til gengæld er der både forskere, forskningsmiljøer og forskningsprojekter, der enten beskæftiger sig indgående med eller berører islam og/eller muslimer som en tematik, der viser sig relevant i relation til processer i samfundet i dag. Netop engagementet i samfundsudvikling og RUCs tværfaglige profil kan siges at være afgørende for den forskning om islam og muslimer, der bedrives på RUC.

RUCs forskning i islam afspejler således, at islam oftest ikke er det primære genstandsfelt. I stedet er det kulturmøder, byrum, mode, forbrug, multikulturalisme, radikalisering, udvikling, ungdomskultur, integrationspolitik, sekularisme, regulering af religion, repræsentation, samfundsdiskurser etc. I disse sammenhænge kan islam og/eller muslimer dukke op som relevante aspekter, objekter eller subjekter. Heraf følger således også et dominerende fokus på samfundets relationer til og interaktioner med islam og/eller muslimer og omvendt snarere end på ideen om islam som en klart afgrænset og identificerbar størrelse, der primært må studeres som religion i en ontologisk givet og institutionaliseret form. I stedet for at fokusere på, hvad nogle ville pege på som indholdet $\mathrm{i}$ islam, undersøger RUC-forskere, hvordan muslimske praksisser og identiteter konstant bliver til og bliver forhandlet igennem grænsedragninger, det være sig samfundets, dets institutioners, eller borgeres, herunder muslimers egne. Denne tilgang betyder, at islam som religiøs praksis og overbevisning i nogle tilfælde viser sig at være en drivende kraft inden for det genstandsfelt, der forskes i. I andre tilfæl-

Lise Paulsen Galal, ph.d., er lektor i Kultur- og Sprogmødestudier, Institut for Kommunikation og Humanistisk Videnskab, Roskilde Universitet. 
de dukker islam som tema op i form af repræsentationer af islam og muslimer eller som genstand for politiske diskurser og reguleringer. Endelig kan islam dukke op i studier af social interaktion i forskellige kontekster, hvor islam som forskelssætning gøres relevant i samspil med andre forskelssætninger (f.eks. køn, seksualitet, race, etnicitet, klasse).

Der er flere forskningsmiljøer på RUC, der på denne måde bidrager med ny viden om islam og muslimer i Danmark såvel som globalt, men islamforskningens mangfoldige karakter på RUC gør det svært at yde den fuld retfærdighed i en beskrivelse som denne. Det følgende dækker derfor ikke al forskning i islam og muslimer på RUC, men giver et indblik i dele af den eksisterende forskning.

\section{Interkulturelle studier}

En af de forskningsgrupper, hvor islam og muslimer til stadighed dukker op som tema, er Interkulturelle Studier, der har eksisteret siden 2007. Interkulturelle studier er en tværfaglig forskningsgruppe, der er vokset ud af studieretningen Kulturog Sprogmødestudier, der blev etableret i 2000, og som nu ligger under Institut for Kommunikation og Humanistisk Videnskab. Dets interesseområde er ikke som sådan defineret som værende islam eller religion. I stedet tager forskningen udgangspunkt i samfundsmæssige processer, der udspringer af globalisering, internationalisering, postkolonialisme og hertil knyttede fænomener, som f.eks. migration, racisme eller kulturel og sproglig diversitet. Mens genstandsfeltet for denne forskning både kan være sociale, kulturelle og politiske praksisser, identifikationer og repræsentationsformer, har forskerne i gruppen det tilfælles, at de er optaget af at undersøge sammenhænge mellem praksis, identifikation og repræsentation med særlig opmærksomhed på grænsedragninger, relationer og de heri indlejrede asymmetriske magtforhold. Det giver næsten sig selv, at islam og muslimer må dukke op i denne forskningsmæssige sammenhæng, primært af to grunde: for det første fordi islam er blevet en langt større del af den europæiske virkelighed på grund af globalisering og migration; for det andet fordi islam de seneste årtier er blevet genstand for en voldsom politisering og sikkerhedsliggørelse globalt såvel som i Danmark. I den forbindel- 
se er islam blevet genstand for politisk styring, populisme, racisme og repræsentation. Men muslimer er også aktører, som bidrager til samfundets diversitet. Det gør de på mange måder, hvor islam langtfra altid spiller en rolle. Når islam spiller en rolle, bliver det derfor interessant at undersøge, hvordan muslimer selv tillægger islam og det at være muslim betydning i praksis og i relation til andre. Ved netop ikke at gøre islam til genstandsfelt, bliver det muligt at undersøge, hvordan islam og muslimer dukker op og gøres relevante - af muslimer, ikkemuslimer og det omkringliggende samfund - i disse samfundsmæssige processer. De følgende eksempler illustrerer denne pointe.

\section{Organiserede kulturmøder}

Begrebet "det organiserede kulturmøde" udspringer af et forskningsprojekt, der under ledelse af lektor Lise Paulsen Galal er udviklet i et samarbejde mellem medlemmer af Interkulturelle Studier og er finansieret af det Det Frie Forskningsråd, Kultur og Kommunikation. Projektet påbegyndtes i september 2013 og løber frem til ultimo september 2017. De andre forskere i projektet er lektor Kirsten Hvenegård-Lassen, lektor Lene Bull Christiansen, post.doc Rasmus Præstman Hansen og ph.d. Helle Bach Riis, som alle i forbindelse med projektet er eller har været ansat på RUC. Projektet er symptomatisk for måden, hvorpå islam og muslimer dukker op som tema i den forskning, der bedrives i Interkulturelle Studier, og afspejler samtidig, hvordan islam i samfundet tillægges varierende betydning i forskellige sammenhænge. Organiserede kulturmøder skal forstås som arrangementer af forskellig karakter, der har det tilfælles, at de er organiseret omkring forskelle, der på den ene eller anden måde anses for at være en hindring eller udfordring for f.eks. sameksistens, udvikling, tolerance, profit, fred etc. Disse arrangementer er derfor organiseret med det formål at håndtere sådanne forskelle for derved at overvinde eller vende det problematiske til noget produktivt. Projektet undersøger fem forskellige typer af organiserede kulturmøder, der afspejler, hvordan forskelle betydningstillægges som forskelssættende og dermed gøres til genstand for interventioner som det organiserede kulturmøde. De fem typer af organiserede kulturmøder er 
interreligiøse dialoginitiativer, mangfoldighedstræning, udviklingsturisme, kulturmødeambassadører og Dans i Nordvest. Alle disse organiserede kulturmøder tager afsæt i på den ene eller anden måde at overskride grænser, og i den proces bringes islam nogle gange i forgrunden, andre gange i baggrunden. Hvor islam således oftere end f.eks. buddhisme bliver et omdrejningspunkt for interreligiøs dialog (se f.eks. Galal 2015), synes islam, og for den sags skyld religion i al almindelighed, ikke at være særlig relevant for mangfoldighedstræning af integrationsmedarbejdere, i hvert fald sættes ingen af delene eksplicit i tale. Uanset begge "projekters" potentielle interesse i at hjælpe til integration og sameksistens så gøres islam tilsyneladende kun relevant i den eksplicit religionsdefinerede aktivitet. Dette afspejler den særlige sekulære indretning af Danmark og illustrerer, hvordan islam tillægges forskellig betydning i forskellige domæner af det danske samfund.

På trods af fraværet af islam som tema i den mangfoldighedstræning, som dette forskningsprojekt undersøger, er det paradoksalt nok en forskelssætning, der til gengæld dukker op i konkrete sociale indsatser, som f.eks. praktiksamtaler med immigranter. Lektor Louise Tranekjær, medlem af forskergruppen Interkulturelle Studier, viser således i bogen Interactional Categorization and Gatekeeping. Institutional Encounters with Otherness (2015), hvordan islam og kropstegn tilskrevet islam igen og igen bliver et omdrejningspunkt i praktiksamtaler. Praktiksamtalerne er et skridt på vejen til et ulønnet praktikophold med det formål at bringe immigranten nærmere arbejdsmarkedet. Baseret på en analyse af en række sådanne praktiksamtaler viser Tranekjær, hvordan arbejdsgivere og jobkonsulenter forsøger at begrebsliggøre, kategorisere og adressere kandidaternes sproglige, etniske og religiøse andethed, og hvordan disse er spundet ind i aktuelle samfundsmæssige diskussioner. De nævnte forskningsprojekter er således eksempler på studier af, hvordan der bevidst arbejdes med en mangfoldighed, der nogle gange og andre gange ikke rummer en opmærksomhed på religiøse forskelle og tilhørsforhold. 


\section{Rum og grænser}

I 2015 udkom doktorafhandlingen Nørrebros indvandringshistorie 1885-2010, skrevet af Garbi Schmidt, der er professor mso og leder af forskningsgruppen Interkulturelle Studier. I Schmidts forskningsprojekt om Nørrebro spiller islam også en rolle, ikke mindst i beskrivelsen af bydelen fra 1980 og frem. Projektet beskriver, hvordan islam historisk set kom til at spille en rolle $\mathrm{i}$ debatten om indvandring til bydelen, hvornår islam og muslimer blev synlige, og hvornår islam og muslimer begyndte at blive italesat som problemer. Projektet fokuserer også på, hvordan muslimsk identitet kan blive anvendt i politisk øjemed i det, som Schmidt kalder for "hverdagens politik" - herunder på gadeplan, som f.eks. under demonstrationer og processioner. Projektet er på flere måder en fortsættelse af Schmidts tidligere forskning om muslimsk ungdomsidentitet, aktivisme og transnationale forbindelser i Skandinavien og USA, der blandt andet resulterede i bogen Muslim i Danmark - muslim i verden. En analyse af muslimske ungdomsforeninger og muslimsk identitet $i$ årene op til Muhammad-krisen (2007).

Interessen for islam og muslimer i et rumligt og urbant perspektiv er også et område, som geografer ved RUC har forsket i. Professor Kirsten Simonsen og lektor Lasse Koefoed har således i projektet “'Den fremmede', byen og nationen - om møder, grænser og socio-rumlig praksis" og senest sammen med Maja de Neergaard i projektet "Paradoxial Spaces: Encountering the Other in public space", begge finansieret af Det Frie Forskningsråd, Samfund og Erhverv, arbejdet med byrum og herunder også islams og muslimers placering heri. Med det rumlige perspektiv undersøges, hvordan islam og muslimer dukker op og gøres relevante som forskelssættende på forskellige måder i forskellige rum. En række artikler er udgivet på baggrund af denne forskning ud over bogen "Den fremmede", byen og nationen: om livet som etnisk minoritet (2010).

\section{Repræsentationer}

Et andet tema, som flere forskere ved RUC har arbejdet med, er mediernes dækning af islam og muslimer. F.eks. har lektor 
Randi Marselis blandt andet skrevet om fremstillingen af muslimer i dansk tv-dokumentarisme og om webbaserede livshistorier, herunder hvordan en ung mand med muslimsk baggrund oplever fremstillingen af sin egen livshistorie. Lektor Rikke Andreassen har skrevet om repræsentationer af den muslimske kvinde. Det er dog ikke kun i medierne, at islam og muslimer repræsenteres. Dette sker også i f.eks. litteratur eller hverdagssamtaler.

Et eksempel på litterære repræsentationer er et aktuelt ph.d.projekt om samtidig marokkansk litteratur. I dette projekt sætter ph.d.-stipendiat Tina Dransfeldt Christensen fokus på, hvilke muligheder litteraturen giver for at italesætte tabuiserede emner og dermed skubbe til den offentlige debat om f.eks. homoseksuelles rettigheder. I denne sammenhæng kommer projektet bl.a. i berøring med, hvordan islam er blevet aktiveret som argument både for og imod LGBT-rettigheder i Marokko.

Forskningsprojektet "Defining and Identifying Middle Eastern Christian Communities in Europe" er et europæisk forskningsprojekt finansieret af HERA (Humanities in the European Research Area) i perioden september 2013 til september 2015. Heri har lektor Lise Paulsen Galal og postdoc Sara Lei Sparre forsket i mellemøstlige kristne i Danmark og deres møder med Danmark, andre kristne og andre migrantgrupper. I den sammenhæng blev de mellemøstlige kristnes narrativer om islam og muslimer i både oprindelseslandet og Danmark et redskab til grænsedragning og afstandtagen og ikke mindst til identifikation med det kristne Danmark. Indeværende nummers artikel af Sara Lei Sparre illustrerer denne problematik.

\section{Muslimske identitetspolitikker}

At religion er omdrejningspunkt for forskellige former for identitetspolitikker, er hverken et nyt eller et særligt muslimsk fænomen. Muslimske identitetspolitikker er dog genstand for megen forskning af samme grunde, som nævnes i introduktionen til denne artikel. De er samtidig meget forskellige og kan studeres fra flere perspektiver. Man kan argumentere for, at det er forskning i identitetspolitikker, der på RUC mest eksplicit har islam og/eller muslimer som genstandsfelt. Der er flere eksempler, hvoraf jeg vil nævne følgende: 
Ved Institut for Samfundsvidenskab og Erhverv har lektor Johan Fischer således forsket i og udgivet flere bøger og artikler om halal (det tilladte) som definerende for et muslimsk forbrug i overensstemmelse med islam. I bogen Halal Matters (2016) præsenteres således en række analyser af halal-praksisser i et globalt perspektiv. Det fremgår, at markedet for halal-produkter er ekspansivt, men også indlejret i politiske, sociale og økonomiske kampe og forhandlinger. Ved det tidligere Institut for Samfund og Globalisering arbejdede daværende lektor Connie Carøe Christiansen ligeledes med et forbrugsperspektiv i sin forskning i islamisk mode. Denne forskning endte bl.a. med et bidrag til bogen Islamic Fashion and Anti-Fashion: New Perspectives from Europe and America (2013).

Flere ph.d.-projekter har de senere år taget afsæt i muslimske identitetsforhandlinger og -politikker. Således skrev Iram Khawaja ph.d. om "To belong everywhere and nowhere: fortællinger om muslimskhed, fællesgørelse og belonging” (2010). Monique Hocke skrev ph.d. om "Narratives of piety: an analysis of the formation of moral selves among young Muslim women in Denmark" (2014). Aktuelt arbejder Sara Jul Jacobsen på et ph.d.-projekt om, hvordan danske salafi-jihadi-grupper agerer online, og særligt hvordan de konstruerer "den muslimske kvinde". Konstruktionen heraf undersøger hun ved at analysere tekster, video og billeder, som danske salafi-jihadi-grupper uploader online, og gennem en analyse af muslimske kvinders online-forhandlinger og legitimeringer af synspunkter, blandt andet med henvisning til islamisk litteratur og islamiske autoriteter. Jacobsens artikel i indeværende nummer er en del af dette projekt.

\section{Styring af religiøs mangfoldighed}

Som det sidste eksempel på forskning på RUC, der inddrager islam og/eller muslimer, vil jeg nævne den forskning, der arbejder med, hvordan et flerkulturelt og flerreligiøst samfund organiseres, institutionaliseres og styres. Her har professor Lisbet Christoffersen ved Institut for Samfundsvidenskab og Erhverv udgivet adskillige bøger, rapporter og artikler om den religionsretslige tilstand i Danmark og dens betydning for religiøse minoriteter, herunder muslimer. På samme måde har Sune 
Lægaard, lektor og viceinstitutleder ved Institut for Kommunikation og Humanistisk Videnskab, forsket i multikulturalisme i et filosofisk perspektiv. Han har bl.a. udgivet en række artikler om religionsfrihed, betydningen af religiøse symboler og om kontroversielle sager, der knyttes til islam.

\section{Litteratur}

Andreassen, Rikke. 2013a. “Take off that Veil and Give me Access to Your Body: An Analysis of Danish Debates About Muslim Women's Head and Body Covering." In Marlou Schrover og Deirdre M. Moloney (eds.): Gender, migration and categorisation: Making distinctions between migrants in Western countries, 1945-2010, 215-229. Amsterdam: Amsterdam University Press B.V.

Andreassen, Rikke. 2013b. "Muslim women and interracial intimacies." Nordic Journal of Migration Research 3: 117-125.

Christensen, Tina Dransfeldt. 2016 "'Writing the self' as narrative of resistance: L'Armée du salut by Abdellah Taïa." The Journal of North African Studies 21(5): 857876.

Christiansen, Connie Carøe. 2013. “"Miss Headscarf', Islamic fashion and the Danish media." In Annelies Moors og Emma Tarlo (eds.): Islamic Fashion and AntiFashion: New Perspectives from Europe and America, 225-238. Bloomsbury Academic.

Christoffersen, Lisbet. 2013. "Sacred Spaces in Secular (post)Lutheran Contexts: on the Danish Church Asylum Case." In Rosemarie Van Den Bremer, José Casanova and Trygve Wyller (eds.): Secular and Sacred? The Scandinavian Case of Religion in Human Rights, Law and Public Space, 102-122. Göttingen/Bristol: Vandenhoeck \& Ruprecht.
Christoffersen, Lisbet. 2012. "The Danish Cartoons Crisis revisited." In W. Cole Durham Jr., David Kirkham and Tore Lindholm (eds.): Islam and Political-Cultural Europe, 217-228. Farnham UK \& Burlington USA: Ashgate. Christoffersen, Lisbet, Hans Raun Iversen, Niels Kærgård og Margit Warburg (eds.). 2012. Fremtidens danske religionsmodel. København: Forlaget Anis. Fischer, Johan and John Lever. 2017. Between Religion, Regulation and Consumption: Globalising Kosher and Halal Markets. Manchester University Press. Fischer, Johan, John Lever and Florence Bergeaud-Blackler (eds.). 2015. Halal Matters: Islam, Politics and Markets in Global Perspective. London and New York: Routledge.

Galal, Lise Paulsen. 2015. "Dialogens arrangement: Når muslimer og kristne mødes." Journal of Islamic Research 9(2): 48-67.

Hocke, Monique. 2014. Narratives of piety: an analysis of the formation of moral selves among young muslim women in Denmark. Ph.D.-dissertation, Roskilde Universitet.

Khawaja, Iram. 2010. To belong everywhere and nowhere: fortoellinger om muslimskhed, fallesgørelse og belonging. Ph.D.dissertation, Roskilde Universitet. 
Lægaard, Sune. 2016. "What's the problem with symbolic religious establishment? The alienation and symbolic equality accounts." In Cécilie Laborde and Aurélia Bardon (eds.): Religion in Liberal Political Philosophy. Oxford: Oxford University Press.

Lægaard, Sune. 2014. "The Case of the Danish Cartoons Controversy: The Paradox of Civility." In Nilüfer Göle (ed.): Islam and Public Controversy in Europe, 123-136. Aldershot: Ashgate.
Marselis, Randi. 2013. "Migrant life stories and the Web: the experience of having your life story made public." Social Semiotics 23(3): 368-384.

Schmidt, Garbi. 2015. Nørrebros indvandringshistorie 1885-2010. København: Museum Tusculanum.

Schmidt, Garbi. 2012. “'Grounded' Politics: Manifesting Muslim Identity as a Political Factor and Localized Identity in Copenhagen." Ethnicities 12(5): 603-622.
Schmidt, Garbi. 2007. Muslim i Danmark - muslim $i$ verden. En analyse af muslimske ungdomsforeninger og muslimsk identitet $i$ årene op til Muhammad-krisen. Uppsala: Universitetstryckeriet. Simonsen, Kirsten og Lasse Martin Koefoed. 2010. "Den fremmede", byen og nationen: om livet som etnisk minoritet. Frederiksberg: Roskilde Universitetsforlag. Tranekjær, Louise. 2015. Interactional Categorisation and Gatekeeping: Institutional Encounters with Otherness. Bristol: Multilingual Matters. 